\title{
Plasmonic ELISA based on DNA-directed gold nanoparticle growth for Cronobacter detection in powdered infant formula samples
}

\author{
Yunqing Wu, ${ }^{1,2 *}$ Ying Xiong, ${ }^{1,2 *}$ Xuelan Chen, ${ }^{3}+$ Dan Luo, ${ }^{1}$ Bao Gao, ${ }^{1}$ Jing Chen, ${ }^{1,2}$ Xiaolin Huang, ${ }^{1}$ \\ Yuankui Leng, ${ }^{1}$ and Yonghua Xiong ${ }^{1,2} \dagger$ \\ ${ }^{1}$ State Key Laboratory of Food Science and Technology, Nanchang University, Nanchang 330047, P. R. China \\ ${ }^{2}$ Jiangxi-OAI Joint Research Institute, Nanchang University, Nanchang 330047, P. R. China \\ ${ }^{3}$ Key Laboratory of Functional Small Organic Molecule, Ministry of Education, Jiangxi Normal University, Nanchang 330022, P. R. China
}

\section{ABSTRACT}

The traditional gold nanoparticle (AuNP) growthbased plasmonic ELISA (pELISA) strictly and directly controlled by reducing reagents can achieve high sensitivity, but it remains fragile toward the surrounding environment. This work developed a sandwich pELISA for Cronobacter detection in powdered infant formula samples by mediating AuNP growth through DNA. In this assay, DNA adsorbed on the surface of gold nanoseeds guided the anisotropic crystal growth with hydroxylamine as a reducing reagent, and the catalase-hydrogen peroxide $\left(\right.$ Cat $\left.-\mathrm{H}_{2} \mathrm{O}_{2}\right)$ system was introduced to bridge the DNA-directed AuNP growth and pELISA, as such DNA can be cleaved into fragments by the hydroxyl radical generated from oxidation of $\mathrm{H}_{2} \mathrm{O}_{2}$ through Fenton reagents. Under optimized conditions, the proposed pELISA can qualitatively detect Cronobacter species (Cronobacter muytjensii ATCC 51329) by the naked eye with a cut-off limit of $3 \times 10^{5} \mathrm{cfu} /$ $\mathrm{mL}$. This method also revealed a good linear range $(3$ $\times 10^{2}$ to $3 \times 10^{7} \mathrm{cfu} / \mathrm{mL}$ ) for quantitative detection of C. muytjensii ATCC 51329 with a limit of detection of $1.6 \times 10^{2} \mathrm{cfu} / \mathrm{mL}$, which is approximately 162.5 times lower than that of horseradish peroxidase-based conventional ELISA $\left(2.6 \times 10^{4} \mathrm{cfu} / \mathrm{mL}\right)$. By taking advantage of highly stable DNA-directed AuNP growth, the proposed method shows a good performance in powdered infant formula samples spiked with different concentrations of C. muytjensii ATCC 51329 with average recoveries ranging from 90.79 to $119.09 \%$ and coefficient of variation ranging from 4.24 to $9.55 \%$. These values corresponded to an acceptable accuracy and precision for the proposed method. In brief, this

\footnotetext{
Received June 5, 2019.

Accepted July 27, 2019.

*These authors contributed equally to this work.

$\dagger$ Corresponding authors: xuelanchen162@163.com yhxiongchen@163.com
}

work shows potential for screening other analytes in food safety, clinical diagnostics, and environmental monitoring.

Key words: plasmonic enzyme-linked immunosorbent assay, gold nanoparticle growth, DNA-directed, Cronobacter, powdered infant formula

\section{INTRODUCTION}

Plasmonic enzyme-linked immunosorbent assay (pELISA) has emerged as a powerful platform for environment monitoring, food safety control, and clinical diagnosis owing to its ultra-high sensitivity and multiple color response to noble nanoparticles (de la Rica and Stevens, 2013). Currently, pELISA mainly depend on nanoparticle aggregation and growth sensing mode (Zhang et al., 2018; Wu et al., 2019). Nonetheless, most nanoparticle aggregation-based pELISA usually face potential problems, including unstable auto-aggregation and narrow linear detection ranges (Huang et al., 2016). Nanoparticle growth-based pELISA are inclined to obtain high sensitivity owing to the small-to-large nanoparticle morphology change that results in lowto-high extinction coefficient of noble nanoparticles (Liu et al., 2014). The formation and growth kinetics of noble nanoparticles strictly depend on reducing reagents for nanoparticle growth-based pELISA. At high concentration of reducing reagents, the growth kinetics of noble nanoparticles are fast, resulting in a uniform morphology. On the contrary, the kinetics of crystal growth proceed slowly at low concentrations of reducing reagents, thereby contributing to aggregated nanoparticles with ill-defined morphology (de la Rica and Stevens, 2012). Cecchin et al. (2014) reported a sandwich pELISA based on hydrogen peroxide $\left(\mathrm{H}_{2} \mathrm{O}_{2}\right)$ mediated gold nanoparticle (AuNP) growth for ultralow biomarker detection. In this work, altering $\mathrm{H}_{2} \mathrm{O}_{2}$ by approximately $0.05 \mu M$ (from 119.5 to $120 \mu M$ ) can produce significant changes in local surface plasmon resonance of AuNP and color of solution (Cecchin et 
al., 2014). Controlling the growth kinetics of noble nanoparticles by reducing reagents can achieve a high sensitivity. However, growth sensing mode directly derived by reducing reagent is more likely obtain nonreproducible results because most reducing reagents are easily oxidized and influenced by surrounding $\mathrm{pH}$, salt, and temperature at low concentration (Satija et al., 2016). This shortcoming considerably impedes practical applications of nanoparticle growth-based pELISA. Therefore, developing sensitive and robust pELISA remains a prominent challenge.

DNA is a well-known biopolymer and has been used as template to position nanoparticles through DNA metallization or to control the sizes and photoluminescent property of metal fluorescent nanoclusters (Wu et al., 2014; Satyavolu et al., 2016, 2018; Xiong et al., 2018a, 2019). Moreover, single-strand DNA (ss-DNA) can adsorb on noble nanoparticles due to the strong affinity between the nitrogen of DNA bases and noble atoms (Storhoff et al., 2002; Li and Rothberg, 2004). During the synthesis of noble nanoparticles, the ss-DNA attached on the surface of noble nanoparticles guides the anisotropic crystal growth and affects the outcome morphology of individual nanoparticles and final color of colloidal solution (Soh et al., 2015). In the DNA-directed AuNP growth system, excess $\mathrm{NH}_{2} \mathrm{OH}(>20 \mathrm{mM})$ should be introduced to ensure that $\mathrm{Au}^{3+}$ completely reduces to $\mathrm{Au}$ atom and then AuNP anisotropic growth is only relevant to DNA types and amounts adsorbed on the particle surface (Tan et al., 2014; Song et al., 2015a). Furthermore, the high concentration of $\mathrm{NH}_{2} \mathrm{OH}$ makes the crystal grow much faster to uniform size and subtle changes in $\mathrm{NH}_{2} \mathrm{OH}$ concentration cannot make a big difference to the final morphology of AuNP because the $\mathrm{NH}_{2} \mathrm{OH}$ concentration largely exceeds the $\mathrm{Au}^{3+}$ concentration (Wang et al., 2010). Therefore, DNA-directed AuNP growth is a desirable tool to regulate the local surface plasmon resonance of AuNP in fabricating robust plasmonic sensors. To the best of our knowledge, a pELISA performed through mediation of DNA in the growth kinetic of AuNP has not been reported.

In this work, we report the pELISA performed through mediation of DNA in the growth kinetics of AuNP to control the morphology of resulting AuNP. The ss-DNA is easily sheared by trace amounts of hydroxyl radical $(\cdot \mathrm{OH})$, which generates damaged DNA bases, such as 8-oxoguanine, 8-oxoadenine, thymine glycol, and 8-hydroxycytosine. The damaged DNA cannot attach on the surface of the gold nanoseeds (AuNS); therefore, no DNA can guide the crystal growth of the gold, and $\cdot \mathrm{OH}$ could be produced by Fenton reagent $\left(\mathrm{Fe}^{2+}\right.$ ) catalyzed $\mathrm{H}_{2} \mathrm{O}_{2}$ (Tang et al., 2006). Therefore, to integrate DNA-mediated growth kinetic of AuNP into conventional ELISA, a catalase (Cat) $-\mathrm{H}_{2} \mathrm{O}_{2}$ system was used to bridge the pELISA and DNA-mediating AuNP growth. Cronobacter was selected as the model target given its association with the disease outbreak causing premature and immunocompromised infants by contaminating infant formula (Ling et al., 2018; Liu et al., 2018). Under optimized conditions, the proposed pELISA can qualitatively detect Cronobacter species (Cronobacter muytjensii ATCC 51329) by the naked eye with a cut-off limit of $3 \times 10^{5} \mathrm{cfu} / \mathrm{mL}$. This method also revealed a good linear range from $3 \times 10^{2}$ to $3 \times$ $10^{7} \mathrm{cfu} / \mathrm{mL}$ for quantitative detection of $C$. muytjensii ATCC 51329 with a limit of detection (LOD) of $1.6 \times$ $10^{2} \mathrm{cfu} / \mathrm{mL}$, which is approximately 162.5 times lower than that of horseradish peroxidase (HRP)-based conventional ELISA $\left(2.6 \times 10^{4} \mathrm{cfu} / \mathrm{mL}\right)$. The proposed pELISA showed good performance in powdered infant formula (PIF) samples spiked with C. muytjensii ATCC 51329. Recoveries ranged from 90.79 to $119.09 \%$ with coefficients of variation (CV) below 10\%. These results demonstrated that our proposed pELISA can be applied for sensitive detection of Cronobacter in real food samples and exhibits potential for detection of other targets.

\section{MATERIALS AND METHODS}

\section{Materials}

Luria-Bertani (LB) broth and Baird-Parker agar base were purchased from Land Bridge Technology Co. Ltd. (Beijing, China). Biotin-3-sulfo- $N$-hydroxysuccinimide ester sodium salt, streptavidin (SA), hydroxylamine hydrochloride $\left(\mathrm{NH}_{2} \mathrm{OH} \cdot \mathrm{HCl}\right)$, Cat, $\mathrm{HRP}$, iron (II) chloride tetrahydrate, hydrogen peroxide $\left(\mathrm{H}_{2} \mathrm{O}_{2}\right.$, $35 \mathrm{wt} \%)$, chloroauric acid $\left(\mathrm{HAuCl}_{4} \cdot 3 \mathrm{H}_{2} \mathrm{O}\right)$, trisodium citrate $\left(\mathrm{Na}_{3} \mathrm{C}_{6} \mathrm{H}_{5} \mathrm{O}_{7} \cdot 2 \mathrm{H}_{2} \mathrm{O}\right)$, and $\mathrm{BSA}$ were purchased from Sigma-Aldrich (St. Louis, MO). The ss-DNA (5'-TAGCTATGG-3') was commercially synthesized by Sangon Biological Engineering Technology and Service Co. Ltd. (Shanghai, China). Our laboratory prepared monoclonal antibody against C. muytjensii ATCC 51329 and minimal cross-reacted with Cronobacter dublinensis China Center of Industrial Culture Collection (CICC) 24179, Cronobacter turicensis CICC 24178, and C. muytjensii SR 1074B. This antibody labeled as 5H-6 is utilized as capture (cAb) and detection antibodies $(\mathbf{d A b})$ at the same time. The 96 -well polystyrene plates were obtained from Corning Inc. (New York, NY). The $180 \mathrm{~nm}$ magnetic beads (MB) were obtained from Allrunnano Technology Co. Ltd. (Shanghai, China). The 
deionized water used throughout the experiments was purified and prepared by using a Milli-Q system (Millipore, Milford, MA). All other chemical reagents were of analytical grade and purchased from Sinopharm Chemical Corp. (Shanghai, China). All reagents were used without further purifications.

\section{Bacteria Strains and Culture Conditions}

Supplemental Table S1 (https://doi.org/10.3168/jds .2019-17067) shows the bacterial strains used in this study. All bacterial strains were grown overnight in LB broth medium in an orbital shaker incubator at 180 rpm at a temperature of $37^{\circ} \mathrm{C}$. The collected bacterial pellets were resuspended in PBS and stored at $4^{\circ} \mathrm{C}$ for further utilization. The viable cell count of bacterial strains was determined by surface plating with 100 $\mu \mathrm{L}$ of suspension liquid through a conventional plate counting method. All counting results were counted as colony-forming units. The bacterial samples were sterilized before use for safety.

\section{Synthesis of Citrated-Capped AuNS and Procedure of DNA-Mediating AuNP Growth}

A hydrothermal citrate-induced reduction method was used for the synthesis of citrate-capped AuNS with an average diameter of $13 \mathrm{~nm}$ (Liang et al., 2018). In brief, $250 \mathrm{~mL}$ of $1 \mathrm{mM} \mathrm{HAuCl}{ }_{4} \cdot 3 \mathrm{H}_{2} \mathrm{O}$ solution was boiled under vigorous stirring in a conical flask. After 5 min of reflux, $25 \mathrm{~mL}$ of $38.8 \mathrm{mM} \mathrm{Na}_{3} \mathrm{C}_{6} \mathrm{H}_{5} \mathrm{O}_{7}$ was rapidly added. The reaction was continually heated for 15 min. During this process, the hue of the mixture changed from earthy yellow to dark red, indicating the formation of citrate-capped AuNS. The resultant solution was immediately kept in an ice bath for another $15 \mathrm{~min}$ to terminate the reaction and then filtrated by a $0.22 \mu M$ filter membrane. Figure $3 \mathrm{C}(\mathrm{a})$ shows the transmission electron microscopy images of the obtained AuNS. The concentration of obtained AuNS was approximately $16.3 \mathrm{n} M$ according to Beer's law.

The DNA-mediating AuNP growth was based on a modified previous method (Wang et al., 2010). A total of $40 \mu \mathrm{L}$ of AuNS $(16.3 \mathrm{nM})$ was first incubated with $40 \mu \mathrm{L}$ of DNA $(10 \mu M)$ for 2 min to allow DNA adsorption onto the AuNS surface. A total of $20 \mu \mathrm{L}$ of $\mathrm{NH}_{2} \mathrm{OH} \cdot \mathrm{HCl}(80 \mathrm{mM})$ was then added to the AuNS solution. After vortexing, $20 \mu \mathrm{L}$ of $\mathrm{HAuCl}_{4} \cdot 3 \mathrm{H}_{2} \mathrm{O}(1$ $\mathrm{m} M$ ) was introduced to the AuNS mixture solution to initiate reduction reaction. A change in color (depending on the amounts of intact DNA absorbed on AuNS surface) was observed in seconds.

\section{pELISA for Cronobacter Detection}

The 96-well plates were coated overnight with $80 \mu \mathrm{L}$ of cAb $(10 \mu \mathrm{g} / \mathrm{mL})$ in bicarbonate buffer $(0.01 \mathrm{M}, \mathrm{pH} 8.6)$ at $4^{\circ} \mathrm{C}$ and then blocked with $1 \mathrm{mg} / \mathrm{mL}$ BSA solution at $37^{\circ} \mathrm{C}$ for $1 \mathrm{~h}$. After washing thrice with PBS-Tween (PBST), $80 \mu \mathrm{L}$ of the desired final concentrations of Cronobacter was added and incubated at $37^{\circ} \mathrm{C}$ for 1 h. After washing thrice with PBST, $80 \mu \mathrm{L}$ of dAb@ Bio $(10 \mu \mathrm{g} / \mathrm{mL})$ was added for 45 min incubation at $37^{\circ} \mathrm{C}$. After washing the plate thrice with PBST, $80 \mu \mathrm{L}$ of SA $(1.25 \mu \mathrm{g} / \mathrm{mL})$ was added. Following the $30 \mathrm{~min}$ reaction at $37^{\circ} \mathrm{C}$ and after washing the plates thrice with PBST, $80 \mu \mathrm{L}$ of Cat@Bio $(2.5 \mu \mathrm{g} / \mathrm{mL})$ was added into each well for $45 \mathrm{~min}$ incubation at $37^{\circ} \mathrm{C}$. Then, the plate was washed 4 times with PBST and twice with ultrapure water, followed by addition of $80 \mu \mathrm{L}$ of $\mathrm{H}_{2} \mathrm{O}_{2}$ $(100 \mu M)$ for $30 \mathrm{~min}$ incubation at $37^{\circ} \mathrm{C}$. Thereafter, 30 $\mu \mathrm{L}$ of $\mathrm{Fe}^{2+}(2 \mathrm{mM})$ and $40 \mu \mathrm{L}$ of DNA $(10 \mu M)$ were added into each plate well for another 30 min reaction. Eventually, $40 \mu \mathrm{L}$ of each plate well with resultant solution containing intact ss-DNA and DNA fragments was used for routine DNA-capped AuNP synthesis similar to that described previously. Colorimetric signal was detected by the naked eye and microplate reader. The HRP-based conventional ELISA was developed for comparison with detailed procedures provided in the Supplemental Information (https://doi.org/10.3168/ jds.2019-17067).

\section{Sample Pretreatment}

Cronobacter muytjensii ATCC 51329 was pretreated by using our previously developed 2-step large-volume immunomagnetic separation method (Luo et al., 2017). Different concentrations of C. muytjensii ATCC 51329 were separately added into $10 \mathrm{~g}$ of PIF. The samples spiked with C. muytjensii ATCC 51329 were mixed with $90 \mathrm{~mL}$ of sterilized PBS to achieve a $10 \%$ infant formula solution. All samples were prepared in triplicate. A total of $3 \mu \mathrm{g}$ of $\mathrm{dAb} @$ Bio was added to 10 $\mathrm{mL}$ of infant formula solution spiked with $C$. muytjensii ATCC 51329. After incubation at $37^{\circ} \mathrm{C}$ for $1 \mathrm{~h}$ with gentle shaking, $700 \mu \mathrm{g}$ of SA-modified MB (MB@SA) was subsequently added into the mixture solution at room temperature for $90 \mathrm{~min}$ with gentle shaking. Finally, MB@SA@dAb@Bio@C. muytjensii ATCC 51329 complex was separated from the homogenate solution using an external magnetic field and then resuspended in $1 \mathrm{~mL}$ of PBS solution. Cronobacter muytjensii ATCC 51329 was dissociated from the resuspension solution by heating at $90^{\circ} \mathrm{C}$ for 15 min and then separated using 
an external magnetic field. The supernatants containing C. muytjensii ATCC 51329 were analyzed using our proposed pELISA.

\section{RESULTS AND DISCUSSION}

\section{Principle of pELISA for Cronobacter Detection}

A novel pELISA with sandwich format based on DNAdirected AuNP growth as signal output was fabricated for Cronobacter detection, and the detailed principle is shown in Figure 1. In this case, the SA-Bio system was introduced as a bridge for the linking of $\mathrm{dAb}$ with Cat. When Cronobacter was present in the PIF sample, the microorganism was captured by cAb. The dAb@Bio was captured by Cronobacter in the plate well. The SA acted as a scaffold for linking dAb@Bio and Cat@Bio. Thereafter, $\mathrm{H}_{2} \mathrm{O}_{2}$ was consumed by Cat, and a minimal amount of $\cdot \mathrm{OH}$ was generated. Then, a small amount of ss-DNA was damaged and cleaved into fragments by $\cdot \mathrm{OH}$, contributing a large number of intact ss-DNA adsorbed on AuNS. Under high intact ss-DNA coverage, the AuNP developed flower-like morphology by adding $\mathrm{NH}_{2} \mathrm{OH} \cdot \mathrm{HCl}$ to reduce $\mathrm{Au}^{3+}$ into $\mathrm{Au}$, with a resultant blue solution. Conversely, high $\mathrm{H}_{2} \mathrm{O}_{2}$ retention in the plate well led to better $\cdot \mathrm{OH}$ generation, and spherical AuNP were obtained, featuring resultant red solutions. Such morphological and color changes can be further characterized by UV-visible spectrum. Therefore, the concentration of Cronobacter can be qualitatively detected by the naked eye and quantitatively detected by plate reader.

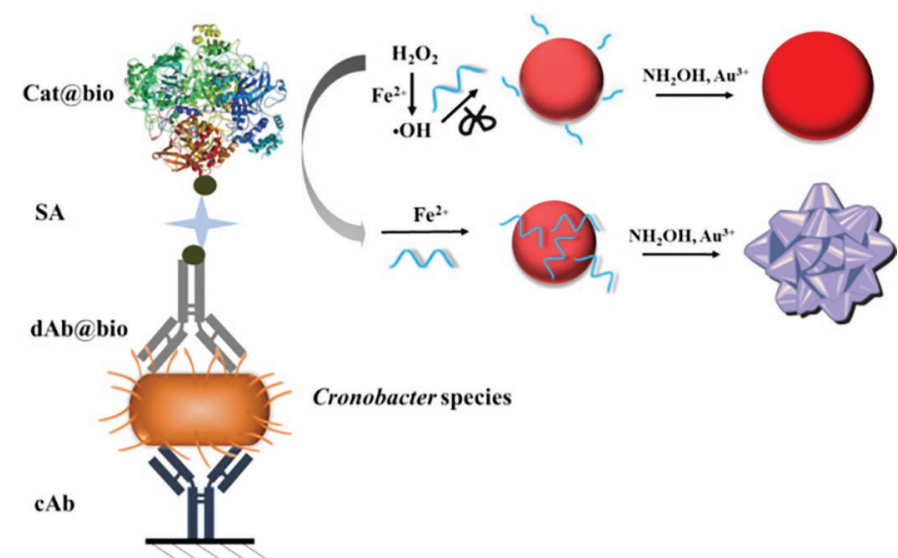

Figure 1. The principle of the proposed plasmonic ELISA. SA $=$ streptavidin $; \mathrm{cAb}=$ capture antibody; $\mathrm{dAb}=$ detection antibody; Cat@bio = biotin-labeled catalase; dAb@bio = biotin-labeled detection antibody.

\section{Validation of AuNP Growth Through DNA Mediation}

To verify the possible application of AuNP growth through DNA mediation in pELISA, we first investigated the influence of $\mathrm{H}_{2} \mathrm{O}_{2}$ on AuNP growth with $\mathrm{NH}_{2} \mathrm{OH} \cdot \mathrm{HCl}$ as a reducing reagent. Normally, special buffer, such as 2-( $N$-morpholino)ethanesulfonic acid, and exact $\mathrm{pH}$ are required for AuNP kinetic growth tuned by $\mathrm{H}_{2} \mathrm{O}_{2}$ (de la Rica and Stevens, 2012; Liu et al., 2014). In our designed DNA-directed AuNP growth system, $\mathrm{NH}_{2} \mathrm{OH}$. $\mathrm{HCl}$ is used to completely consume the $\mathrm{Au}^{3+}$, resulting in an extremely acidic environment, whereas $\mathrm{H}_{2} \mathrm{O}_{2}$ cannot play its reduction activation. As shown in Supplemental Figure S1A, in the absence of $\mathrm{NH}_{2} \mathrm{OH} \cdot \mathrm{HCl}$ and at $\mathrm{H}_{2} \mathrm{O}_{2}$ concentration ranging from 0 to $400 \mu M$ in the AuNP growth system, the color of AuNP solution remained unchanged with a low and stable optical density $(\mathbf{O D})_{520}$ value. However, when $40 \mathrm{mM}$ of $\mathrm{NH}_{2} \mathrm{OH} \cdot \mathrm{HCl}$ was added, the color of AuNP solution notably changed from pale to brick red, and the $\mathrm{OD}_{520}$ value increased from 0.32 to 0.75 . These results proved that $\mathrm{H}_{2} \mathrm{O}_{2}$ was irrelevant for AuNP growth, and $\mathrm{NH}_{2} \mathrm{OH} \cdot \mathrm{HCl}$ was a driving factor for AuNP growth in our designed system. In addition, the effect of $\mathrm{NH}_{2} \mathrm{OH} \cdot \mathrm{HCl}$ concentration on AuNP growth response was investigated over a range of $0 \mathrm{~nm}$ to 160 $\mathrm{m} M$ as excessive amounts of $\mathrm{NH}_{2} \mathrm{OH} \cdot \mathrm{HCl}$ can cause the aggregation of AuNP (Tan et al., 2017). The results in Supplemental Figure S1B (https://doi.org/10.3168/jds .2019-17067) show that when $\mathrm{NH}_{2} \mathrm{OH} \cdot \mathrm{HCl}$ concentration was above $80 \mathrm{mM}$, the solution color changed from red to blue, and absorbance presented a significant red shift. Thus, $80 \mathrm{mM} \mathrm{NH} \mathrm{NH}_{2} \mathrm{OH} \cdot \mathrm{HCl}$ was selected for the following experiment. Moreover, excess $\mathrm{Fe}^{2+}$ can adsorb on the surface of citrated AuNP screening the negative charge of AuNP and result in aggregation of AuNP (Sang et al., 2010; Xiong et al., 2018b). The effect of $\mathrm{Fe}^{2+}$ on AuNP growth was evaluated by adding 0 to 16 $\mathrm{m} M \mathrm{Fe}^{2+}$ into AuNP growth solution containing $80 \mathrm{mM}$ $\mathrm{NH}_{2} \mathrm{OH} \cdot \mathrm{HCl}$. Results showed no remarkable color or absorbance change in the resultant solution when $\mathrm{Fe}^{2+}$ concentration was below $4 \mathrm{mM}$ (Supplemental Figure S1C; https://doi.org/10.3168/jds.2019-17067). Finally, $2 \mathrm{mM} \mathrm{Fe}{ }^{2+}$ was used for the following experiments because this concentration is sufficient to convert $\mathrm{H}_{2} \mathrm{O}_{2}$ into $\cdot \mathrm{OH}$.

A previous study demonstrated that the morphology of AuNP growth is independent of the length of DNA sequences (Wang et al., 2012). Moreover, the synthesis of a short DNA sequence (e.g., less than 5 bases) is technically difficult. Thus, a ss-DNA of 9 bases with a random sequence was designed to mediate the anisotropic crystal growth of AuNP. The effect of the extent 

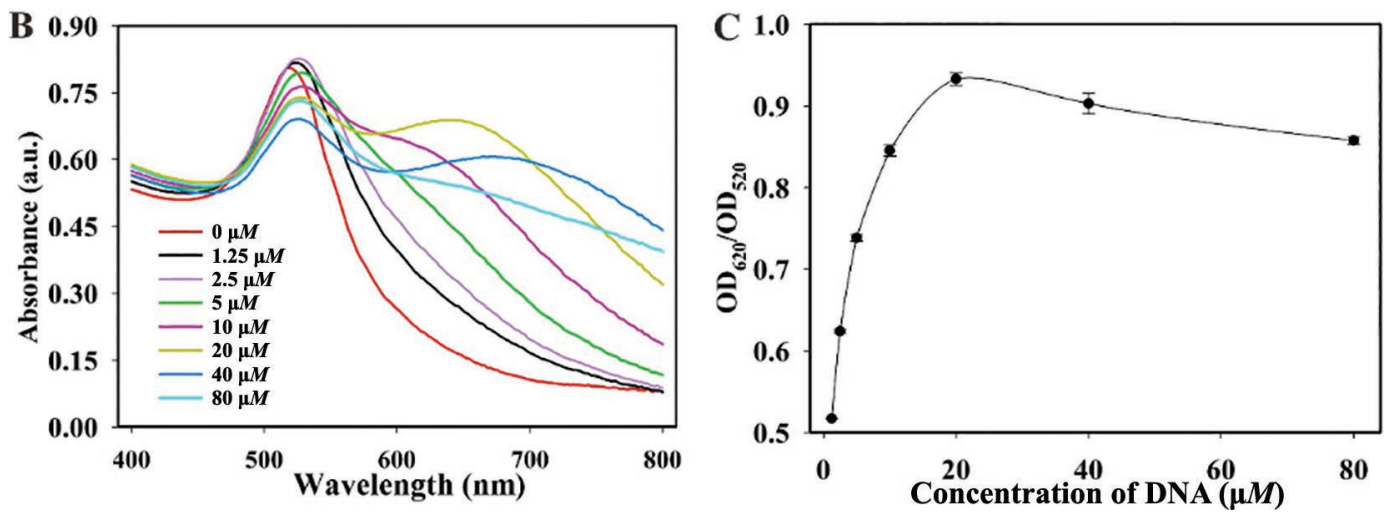

Figure 2. (A) Photographs of resultant gold nanoparticle (AuNP) solution with the addition of different DNA concentrations. (B) Ultravioletvisible absorption spectra of resultant AuNP solution with the addition of different DNA concentrations. (C) Corresponding optical density at $620 \mathrm{~nm}\left(\mathrm{OD}_{620}\right) /$ optical density at $520 \mathrm{~nm}\left(\mathrm{OD}_{520}\right)$ of the resultant AuNP solution with the addition of different DNA concentrations. Each value represents the mean of 3 independent experiments $(\mathrm{n}=3)$. Error bars represent SD of 3 measurements. a.u. $=$ arbitrary units.

of ss-DNA adsorption on AuNP growth reaction was investigated. As evident in Figure 2A, the color of AuNP solution changed from red to purple and blue as ss-DNA amounts increased in a typical AuNP growth run. The corresponding UV-visible absorption spectra showed that the red AuNP solution exhibited a single surface plasmon resonance peak centered at $520 \mathrm{~nm}$, whereas the purple and blue AuNP solutions displayed 2 peaks at 520 and $620 \mathrm{~nm}$, respectively (Figure 2B). For convenience of characterizing surface plasmon resonance changes, the absorbance ratio $\left(\mathrm{OD}_{620} / \mathrm{OD}_{520}\right)$ was used to evaluate the optimal parameters for the following experiments. A large $\mathrm{OD}_{620} / \mathrm{OD}_{520}$ indicates the flower-like appearance of resulting AuNP due to high amounts of ss-DNA adsorbed on AuNP. On the contrary, adsorption of low amounts of ss-DNA on AuNP led to spherical shapes in the outcome AuNP. As shown in Figure $2 \mathrm{C}$, the value of $\mathrm{OD}_{620} / \mathrm{OD}_{520}$ increased as ss-DNA concentration increased from 0 to $10 \mu \mathrm{M}$. The value started to plateau when ss-DNA concentration further increased. The AuNP solution turned blue with $10 \mu M$ ss-DNA mediating the AuNP growth. Such change in color is easily distinguished from that of AuNP solution without DNA mediation. Therefore, 10 $\mu M$ ss-DNA was applied for mediating AuNP growth.

In addition, $\mathrm{H}_{2} \mathrm{O}_{2}$ is an important component in determining the sensitivity of pELISA because it can be converted into $\cdot \mathrm{OH}$ with the aim of regulating the amounts of intact ss-DNA by $\mathrm{Fe}^{2+}$. Thus, AuNP growth through DNA mediation in the presence of $\mathrm{H}_{2} \mathrm{O}_{2}$ was investigated by incubating $10 \mu \mathrm{M}$ ss-DNA with different concentrations of $\mathrm{H}_{2} \mathrm{O}_{2}$ ranging from 0 to $800 \mu M$ in the presence of $2 \mathrm{mM} \mathrm{Fe}^{2+}$ for $30 \mathrm{~min}$. Then, a typical DNA-mediating growth reaction was carried out. Figure $3 \mathrm{~A}$ shows that the color of AuNP solution significantly changed from blue to purple and then to red with increasing $\mathrm{H}_{2} \mathrm{O}_{2}$ concentration, whereas the corresponding $\mathrm{OD}_{620} / \mathrm{OD}_{520}$ decreased from 0.56 to 0.23 (Figure $3 \mathrm{~B})$. The $\mathrm{OD}_{620} / \mathrm{OD}_{520}$ value of the AuNP solution also displayed a good linear trend with $\mathrm{H}_{2} \mathrm{O}_{2}$ concentration ranging from 6.25 to $100 \mu \mathrm{M}$, yielding a reliable correlation coefficient of 0.9807 (Figure 3B insert). The LOD of $\mathrm{H}_{2} \mathrm{O}_{2}$ toward the change of $\mathrm{OD}_{620} / \mathrm{OD}_{520}$ value was calculated to be $8.03 \mu M$. Notably, when $\mathrm{H}_{2} \mathrm{O}_{2}$ concentration was $100 \mu M$, a vivid color change from red to blue was observed by the naked eye. The AuNP growth through DNA-mediating in the presence of $\mathrm{H}_{2} \mathrm{O}_{2}$ was further confirmed by transmission electron microscopy. With increasing $\mathrm{H}_{2} \mathrm{O}_{2}$ levels, flower-like AuNP gradually diminished and transformed into a spherical shape similar to the AuNP without DNA adsorption (Figure 3C, a-e). Moreover, good dispersion and physically uniform nanoparticles demonstrated the high stability of our designed AuNP growth system. This finding was also validated by monitoring of $\mathrm{OD}_{620} / \mathrm{OD}_{520}$ values for 2 h. As shown in Supplemental Figure S2 (https: //doi.org/10.3168/jds.2019-17067), the $\mathrm{OD}_{620} / \mathrm{OD}_{520}$ reached the maximum value within 2 min and remained relatively stable for the next $2 \mathrm{~h}$. The above results indicate that the DNA-directed AuNP growth system features the potential to fabricate sensitive and robust pELISA. Finally, to obtain a stable colorimetric signal and spectral signal, we designated $100 \mu M \mathrm{H}_{2} \mathrm{O}_{2}$ as the optimal concentration in the subsequent experiments. 


\section{Optimization of Experimental Parameters and Analytical Performance}

Before establishing the AuNP growth-based pELISA through DNA mediating for Cronobacter detection, several parameters that affect analytical sensitivity, including the concentrations of cAb, dAb@Bio, SA, and Cat@Bio, were investigated. The preparation and characterization of $\mathrm{dAb} @ \mathrm{Bio}$ and Cat@Bio are shown in Supplemental Figures S3A-S3B (https://doi.org/10 .3168/jds.2019-17067). The concentrations of cAb and dAb@Bio were optimized by using checkboard titration with different of dAb@Bio contents under a series of $\mathrm{cAb}$ on the plate well. In this case, the concentration of C. muytjensii ATCC 51329 was set to $10^{6} \mathrm{cfu} / \mathrm{mL}$. The results in Supplemental Table S2 and Figure S4 (https: //doi.org/10.3168/jds.2019-17067) indicate that both $10 \mu \mathrm{g} / \mathrm{mL}$ of $\mathrm{cAb}$ and $10 \mu \mathrm{g} / \mathrm{mL}$ of dAb@Bio were the optimized concentrations for the following experiments. These values were obtained because the plate well of C. muytjensii ATCC 51329 positive sample appeared purple, whereas that of $\mathrm{OD}_{620} / \mathrm{OD}_{520}$ slightly changed when dAb@Bio and cAb continually increased. In addition, the concentrations of SA and Cat@Bio were optimized by determining C. muytjensii ATCC 51329 at $10^{6} \mathrm{cfu} / \mathrm{mL}$. The results in Supplemental Figure S5A (https://doi.org/10.3168/jds.2019-17067) suggest that the $\mathrm{OD}_{620} / \mathrm{OD}_{520}$ increased as $\mathrm{SA}$ concentration increased from 0.31 to $1.25 \mu \mathrm{g} / \mathrm{mL}$. The $\mathrm{OD}_{620} / \mathrm{OD}_{520}$ reached a plateau when the SA concentration was further increased. Thus, $1.25 \mu \mathrm{g} / \mathrm{mL}$ was determined as the optimal concentration of SA in subsequent experiments. Supplemental Figure S5B (https://doi.org/10 $.3168 /$ jds.2019-17067) indicates that the $\mathrm{OD}_{620} / \mathrm{OD}_{520}$ significantly increased from 0.44 to 0.72 as the Cat@ Bio concentration increased from 0.31 to $1.25 \mu \mathrm{g} / \mathrm{mL}$ and then stabilized when Cat@Bio concentration further increased. An excess amount of Cat@Bio benefits the achievement of a stable signal. Thus, $2.5 \mu \mathrm{g} / \mathrm{mL}$ of Cat@Bio was selected as the optimal concentration for the following experiments.

Under optimal conditions, the sensitivity of the proposed pELISA was evaluated by detecting different concentrations of C. muytjensii ATCC 51329 from $3 \times$ $10^{0}$ to $3 \times 10^{8} \mathrm{cfu} / \mathrm{mL}$. The calibration curve was constructed by plotting the $\mathrm{OD}_{620} / \mathrm{OD}_{520}$ values versus the logarithmic of C. muytjensii ATCC 51329 concentration. The linear relationship for quantitative C. muytjensii ATCC 51329 detection ranged from $3 \times 10^{2}$ to $3 \times$ $10^{7} \mathrm{cfu} / \mathrm{mL}$, whereas the regression for quantitative $C$. muytjensii ATCC 51329 detection can be described as $\mathrm{y}=0.0217 \ln (\mathrm{x})+0.3418\left(\mathrm{R}^{2}=0.9932\right)$, as shown in Figure $4 \mathrm{~b}$. The LOD, defined as the blank signal minus 3 standard deviations, of the proposed pELISA for $C$. muytjensii ATCC 51329 detection measured $1.6 \times 10^{2}$ $\mathrm{cfu} / \mathrm{mL}$. This value is approximately 162.5 times lower than that of HRP-based conventional ELISA (Supplemental Figure S6; https://doi.org/10.3168/jds.2019

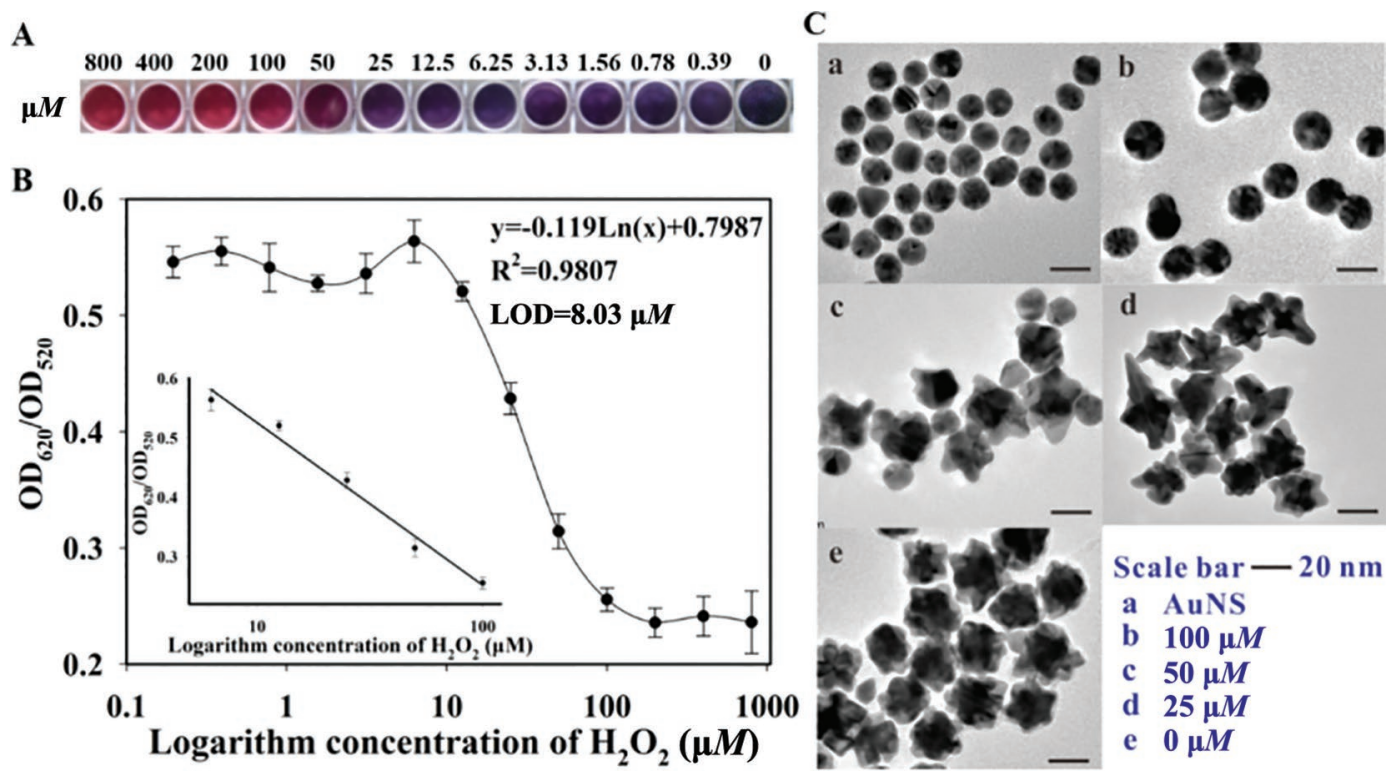

Figure 3. (A) Photograph of resultant gold nanoparticle (AuNP) solution under different concentrations of $\mathrm{H}_{2} \mathrm{O}_{2}$-induced DNA-mediating AuNP growth. (B) Optical density at $620 \mathrm{~nm}\left(\mathrm{OD}_{620}\right) /$ optical density at $520 \mathrm{~nm}\left(\mathrm{OD}_{520}\right)$ value of resultant AuNP solution under different $\mathrm{H}_{2} \mathrm{O}_{2}$ concentrations. (C) Transmission electron microscopy images of resultant AuNP under different concentrations of $\mathrm{H}_{2} \mathrm{O}_{2}$-induced DNA-mediating AuNP growth. (a) Gold nanoseeds (AuNS), (b) $100 \mu M$, (c) $50 \mu M$, (d) $25 \mu M$, and (e) $0 \mu M \mathrm{H}_{2} \mathrm{O}_{2}$. Each value represents the mean of 3 independent experiments $(\mathrm{n}=3)$. Error bars represent $\mathrm{SD}$ of 3 measurements. LOD $=$ limit of detection. 


\section{Concentration of $(3 \times \mathrm{cfu} / \mathrm{mL})$}

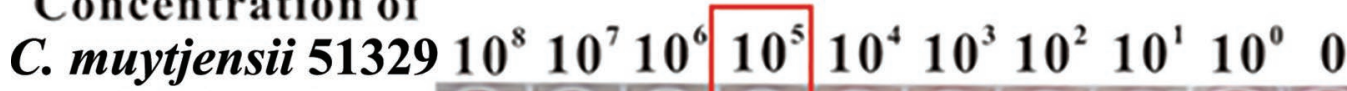

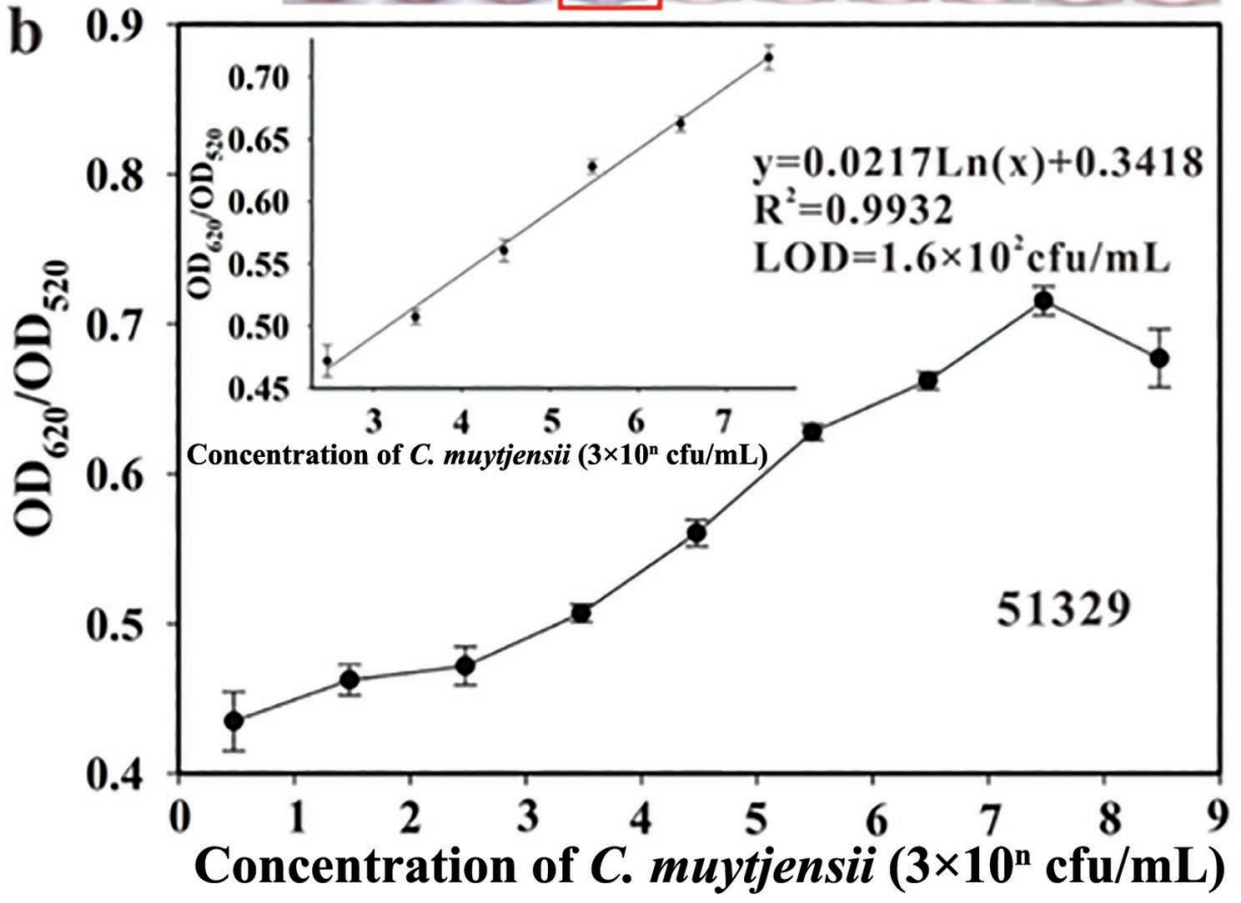

Figure 4. Qualitative or quantitative detection of Cronobacter muytjensii ATCC 51329 with the proposed plasmonic enzyme-linked immunosorbent assay (pELISA). (a) Qualitative detection (naked eye) of $C$. muytjensii ATCC 51329 by using our proposed pELISA with 5 duplications. (b) Calibration curve of C. muytjensii ATCC 51329 detected by the proposed pELISA. Each value represents the mean of 5 independent experiments $(\mathrm{n}=5)$. Error bars represent SD of 3 measurements. OD = optical density; LOD $=$ limit of detection.

-17067). Stereographs in Figure 4a indicate that the AuNP solution produced contrasting colors from red to purple, and no false results were observed in $5 \mathrm{du}-$ plications when C. muytjensii ATCC 51329 concentrations exceeded $3 \times 10^{5} \mathrm{cfu} / \mathrm{mL}$. This color change was easily distinguished by the naked eye, and the robust plasmonic signal output was attributed to the DNAdirected AuNP growth. Eventually, $3 \times 10^{5} \mathrm{cfu} / \mathrm{mL}$ was defined as the cut-off limit for the qualitative detection of C. muytjensii ATCC 51329 by the naked eye. In addition, we further compared the detection performance of our proposed method with that of other reported works. Results in Table 1 reveal that the sensitivity of our method is comparable with that of other methods, and our proposed pELISA possesses advantage in terms of high throughput and stable data collection for the detection of Cronobacter.

To determine the specificity of the proposed method, we performed the proposed pELISA to detect $C$. muytjensii ATCC 51329, Cronobacter sakazakii ATCC 29544, C. turicensis CICC 24178, C. condimenti CICC 24184, Cronobacter malonatics National Center for Medical Culture Collections (CMCC) 45402, C. dublinensis CICC 24179, C. sakazakii YC 633B, C. muytjen- 


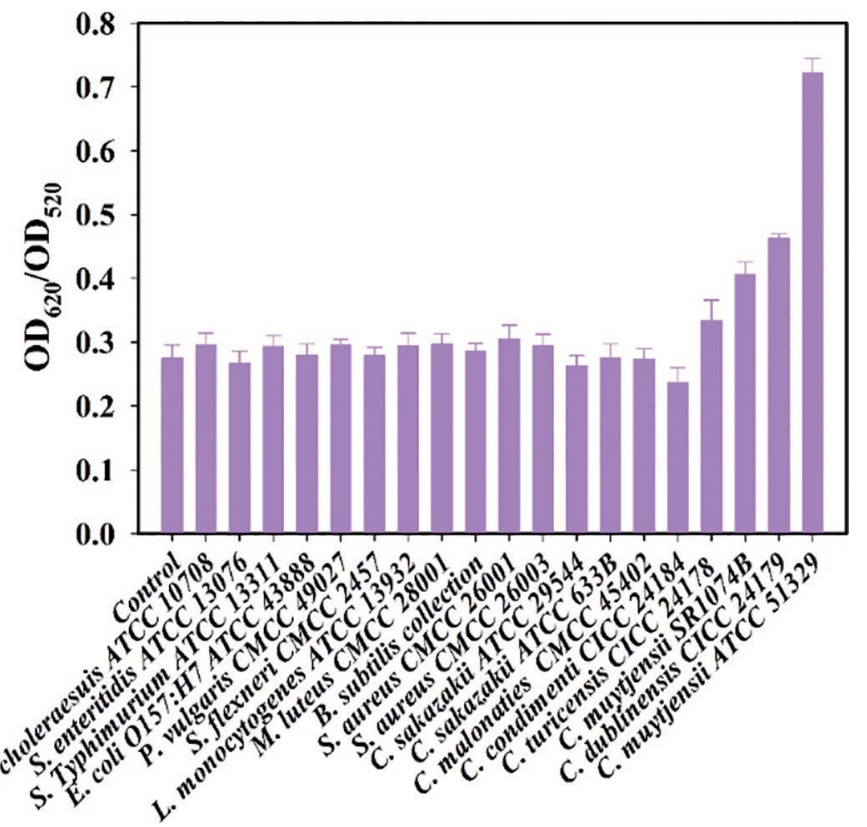

Figure 5. Selectivity of the proposed plasmonic enzyme-linked immunosorbent assay (pELISA). A negative control test was performed by adding sterile PBS solution. Each value represents the mean of 3 independent experiments $(\mathrm{n}=3)$. Error bars represent SD of 3 measurements. OD $=$ optical density; ATCC $=$ American Type Culture Collection; CICC = China Center of Industrial Culture Collection $\mathrm{CMCC}=$ National Center for Medical Culture Collections.

sii SR 1074B, and 11 common pathogenic bacterial strains, including Salmonella choleraesuis, Salmonella enteritidis, Salmonella typhimurium, Shigella flexneri, Listeria monocytogenes, Proteus vulgaris, Escherichia coli O157:H7, Micrococcus lutes, Bacillus subtilis, and 2 Staphylococcus aureus strains. Figure 5 reveals that significant increases in $\mathrm{OD}_{620} / \mathrm{OD}_{520}$ only occurred in the presence of C. muytjensii ATCC $51329\left(10^{7} \mathrm{cfu} /\right.$ $\mathrm{mL}$ ), whereas weak signals for other Cronobacter species and negligible signal changes for nontarget bacteria $\left(10^{7} \mathrm{cfu} / \mathrm{mL}\right)$ were observed. These findings demonstrate the high selectivity of the proposed pELISA for Cronobacter species.
The precision of intra- and interassay was used to evaluate the accuracy of the proposed pELISA by analyzing 4 different concentrations $\left(3 \times 10^{3}, 3 \times 10^{4}, 3 \times\right.$ $10^{5}$, and $3 \times 10^{6} \mathrm{cfu} / \mathrm{mL}$ ) of PIF samples spiked with C. muytjensii ATCC 51329. The intra-assay was carried out in quadruplicate on the same day, whereas interassay was executed on 3 sequential days. Interferences from the infant formula solution matrix were assessed by using 2 -step large-volume immunomagnetic separation for the isolation and enrichment of $C$. muytjensii ATCC 51329 from samples before detection. Table 2 shows the average recovery for intra-assay ranging from 90.79 to $115.90 \%$, with CV ranging from 4.24 to $9.55 \%$. On the other hand, recovery for inter-assay ranged from 92.48 to $119.09 \%$, whereas CV ranged from 5.88 to $9.13 \%$. These results reveal that our developed pELISA exhibits an acceptable level of accuracy for detection of C. muytjensii ATCC 51329.

\section{CONCLUSIONS}

In this study, AuNP growth through DNA mediation was successfully integrated with a conventional ELISA platform to detect Cronobacter in PIF sample by the naked eye and using a plate reader. Compared with reducing reagent-regulated AuNP growth, the DNAdirected AuNP growth is tolerant to the surrounding environment. Therefore, the signal readout is considerably stable. The proposed sandwich pELISA also exhibited an excellent sensitivity for quantitative detection of Cronobacter and good accuracy in PIF samples. The vivid color change from red to blue can be successfully used to screen Cronobacter, and DNA was directly applied to pELISA without complex modification. Consequently, the proposed method is easy and convenient to operate and suitable for use in resourceconstrained regions. Therefore, the developed sandwich pELISA shows potential for naked eye and quantitative detection of other analytes in food safety, clinical diagnostics, and environmental monitoring.

Table 1. Performance comparison of recently reported methods for Cronobacter species detection $^{1}$

\begin{tabular}{|c|c|c|c|c|}
\hline Method & Signal output & $\begin{array}{l}\text { Linear range } \\
(\mathrm{cfu} / \mathrm{mL})\end{array}$ & $\begin{array}{c}\text { LOD } \\
(\mathrm{cfu} / \mathrm{mL})\end{array}$ & Reference \\
\hline $\begin{array}{l}\text { Plasmonic sensor } \\
\text { Plasmonic sensor } \\
\text { Electrochemical sensor } \\
\text { Electrochemical sensor } \\
\text { Electrochemical sensor } \\
\text { PCR } \\
\text { PCR } \\
\text { Immunochromatographic strip } \\
\text { Fluorescent sensor }\end{array}$ & $\begin{array}{l}\text { AuNP growth } \\
\text { AuNP aggregation } \\
\text { Voltammetry } \\
\text { Voltammetry } \\
\text { Voltammetry and current } \\
\text { Fluorescent dye } \\
\text { Fluorescent dye } \\
\text { AuNP } \\
\text { Fluorescent dye }\end{array}$ & $\begin{array}{c}3 \times 10^{2} \text { to } 3 \times 10^{7} \\
7.1 \times 10^{3} \text { to } 7.1 \times 10^{7} \\
10^{4} \text { to } 10^{10} \\
10^{3} \text { to } 10^{9} \\
2.0 \times 10^{2}-2.0 \times 10^{7} \\
\mathrm{NM} \\
\mathrm{NM} \\
\mathrm{NM} \\
\mathrm{NM}\end{array}$ & $\begin{array}{l}1.6 \times 10^{2} \\
7.1 \times 10^{3} \\
4.57 \times 10^{3} \\
1.19 \times 10^{2} \\
2.0 \times 10^{1} \\
1.6 \times 10^{1} \\
10^{2} \\
10^{7} \\
6.3 \times 10^{4}\end{array}$ & $\begin{array}{l}\text { Our method } \\
\text { Kim et al., } 2017 \\
\text { Dou et al., } 2013 \\
\text { Hu et al., } 2015 \\
\text { Shukla et al., } 2018 \\
\text { Ruan et al., } 2013 \\
\text { El-Sharoud et al., } 2013 \\
\text { Chen et al., 2014 } \\
\text { Song et al., 2015b }\end{array}$ \\
\hline
\end{tabular}

${ }^{1} \mathrm{LOD}=$ limit of detection; AuNP $=$ gold nanoparticle; $\mathrm{NM}=$ not mentioned in paper. 
Table 2. Recovery and precision of the proposed plasmonic enzyme-linked immunosorbent assay (pELISA) in Cronobacter muytjensii 51329-spiked milk samples

\begin{tabular}{lccc}
\hline C. muytjensii 51329 added $(\mathrm{cfu} / \mathrm{mL})$ & $\begin{array}{r}\text { C. muytjensii } 51329 \text { detected } \\
(\mathrm{cfu} / \mathrm{mL})\end{array}$ & $\begin{array}{r}\text { Recovery } \\
(\%)\end{array}$ & $\begin{array}{c}\text { CV } \\
(\%)\end{array}$ \\
\hline Intra-day assay $(\mathrm{n}=4)^{1}$ & & & \\
3,000 & 3,141 & 95.51 & 9.55 \\
30,000 & 31,437 & 95.43 & 6.50 \\
300,000 & 258,844 & 115.90 & 4.24 \\
$3,000,000$ & $3,304,329$ & 90.79 & 5.90 \\
Inter-day assay $(\mathrm{n}=3)^{2}$ & & & \\
3,000 & 3,140 & 95.55 & 8.27 \\
30,000 & 32,439 & 92.48 & 9.13 \\
300,000 & 251,910 & 119.09 & 5.88 \\
$3,000,000$ & $2,967,946$ & & 8.27 \\
\hline
\end{tabular}

${ }^{1}$ The assay was carried out in quadruplicates on the same day.

${ }^{2}$ The assay was performed on 3 consecutive days.

\section{ACKNOWLEDGMENTS}

This work was supported by a grant from the National Key Research and Development Program of China (2018YFC1602202 and 2018YFC1602203), National Natural Science Foundation of China (31760485), and "5511" superior science and technology innovation team project of Jiangxi province (China). Ying Xiong acknowledges financial support from the Chinese Scholarship Council.

\section{REFERENCES}

Cecchin, D., R. de la Rica, R. Bain, M. W. Finnis, M. Stevens, and G. Battaglia. 2014. Plasmonic ELISA for the detection of gp120 at ultralow concentrations with the naked eye. Nanoscale 6:9559-9562.

Chen, F., X. Ming, X. Chen, M. Gan, B. Wang, F. Xu, and H. Wei. 2014. Immunochromatographic strip for rapid detection of Cronobacter in powdered infant formula in combination with silicacoated magnetic nanoparticles separation and 16S rRNA probe. Biosens. Bioelectron. 61:306-313.

de la Rica, R., and M. M. Stevens. 2012. Plasmonic ELISA for the ultrasensitive detection of disease biomarkers with the naked eye. Nat. Nanotechnol. 7:821-824.

de la Rica, R., and M. M. Stevens. 2013. Plasmonic ELISA for the detection of analytes at ultralow concentrations with the naked eye. Nat. Protoc. 8:1759-1764.

Dou, W., W. Tang, and G. Zhao. 2013. A disposable electrochemical immunosensor arrays using 4-channel screen-printed carbon electrode for simultaneous detection of Escherichia coli O157: $\mathrm{H} 7$ and Enterobacter sakazakii. Electrochim. Acta 97:79-85.

El-Sharoud, W. M., M. S. Darwish, and C. A. Batt. 2013. A real-time PCR-based microfluidics platform for the detection of Cronobacter sakazakii in reconstituted milks. Int. Dairy J. 33:67-74.

Hu, X. W. Dou, and G. Zhao. 2015. Electrochemical immunosensor for Enterobacter sakazakii detection based on electrochemically reduced graphene oxide-gold nanoparticle/ionic liquid modified electrode. J. Electroanal. Chem. 756:43-48.

Huang, X., R. Chen, H. Xu, W. Lai, and Y. Xiong. 2016. Nanospherical brush as catalase container for enhancing the detection sensitivity of competitive plasmonic ELISA. Anal. Chem. 88:1951-1958.

Kim, H.-S., Y.-J. Kim, J.-W. Chon, D.-H. Kim, J.-H. Yim, H. Kim, and K.-H. Seo. 2017. Two-stage label-free aptasensing platform for rapid detection of Cronobacter sakazakii in powdered infant formula. Sens. Actuators B Chem. 239:94-99.
Li, H., and L. Rothberg. 2004. Colorimetric detection of DNA sequences based on electrostatic interactions with unmodified gold nanoparticles. Proc. Natl. Acad. Sci. USA 101:14036-14039.

Liang, Y., X. Huang, X. Chen, W. Zhang, G. Ping, and Y. Xiong. 2018. Plasmonic ELISA for naked-eye detection of ochratoxin A based on the tyramine- $\mathrm{H}_{2} \mathrm{O}_{2}$ amplification system. Sens. Actuators B Chem. 259:162-169.

Ling, N., C. Li, J. Zhang, Q. Wu, H. Zeng, W. He, Y. Ye, J. Wang, Y. Ding, and M. Chen. 2018. Prevalence and molecular and antimicrobial characteristics of Cronobacter spp. isolated from raw vegetables in China. Front. Microbiol. 9:1149.

Liu, D., J. Yang, H.-F. Wang, Z. Wang, X. Huang, Z. Wang, G. Niu, A. Hight Walker, and X. Chen. 2014. Glucose oxidase-catalyzed growth of gold nanoparticles enables quantitative detection of attomolar cancer biomarkers. Anal. Chem. 86:5800-5806.

Liu, S., Y. Geng, L. Liu, X. Sun, J. Shao, B. Han, J. Wang, and K. Tan. 2018. Development of an isothermal amplification-based assay for the rapid detection of Cronobacter spp. J. Dairy Sci. 101:4914-4922.

Luo, D., X. Huang, Y. Mao, C. Chen, F. Li, H. Xu, and Y. Xiong. 2017. Two-step large-volume magnetic separation combined with PCR assay for sensitive detection of Listeria monocytogenes in pasteurized milk. J. Dairy Sci. 100:7883-7890.

Ruan, J., M. Li, Y.-P. Liu, Y.-Q. Li, and Y.-X. Li. 2013. Rapid and sensitive detection of Cronobacter spp.(previously Enterobacter sakazakii) in food by duplex PCR combined with capillary electrophoresis-laser-induced fluorescence detector. J. Chromatogr. B Analyt. Technol. Biomed. Life Sci. 921-922:15-20.

Sang, Y., L. Zhang, Y. F. Li, L. Q. Chen, J. L. Xu, and C. Z. Huang, 2010. A visual detection of hydrogen peroxide on the basis of Fenton reaction with gold nanoparticles. Anal. Chim. Acta 659:224228

Satija, J., N. Punjabi, D. Mishra, and S. Mukherji. 2016. PlasmonicELISA: Expanding horizons. RSC Advances 6:85440-85456.

Satyavolu, N. S. R., N. Pishevaresfahani, L. H. Tan, and Y. Lu. 2018 DNA-encoded morphological evolution of bimetallic Pd@ Au coreshell nanoparticles from a high-indexed core. Nano Res. 11:45494561.

Satyavolu, N. S. R., L. H. Tan, and Y. Lu. 2016. DNA-mediated morphological control of $\mathrm{Pd}-\mathrm{Au}$ bimetallic nanoparticles. J. Am. Chem. Soc. 138:16542-16548.

Shukla, S., Y. Haldorai, V. K. Bajpai, A. Rengaraj, S. K. Hwang, X. Song, M. Kim, Y. S. Huh, and Y.-K. Han. 2018. Electrochemical coupled immunosensing platform based on graphene oxide/gold nanocomposite for sensitive detection of Cronobacter sakazakii in powdered infant formula. Biosens. Bioelectron. 109:139-149.

Soh, J. H., Y. Lin, S. Rana, J. Y. Ying, and M. M. Stevens. 2015. Colorimetric detection of small molecules in complex matrixes via target-mediated growth of aptamer-functionalized gold nanoparticles. Anal. Chem. 87:7644-7652. 
Song, T., L. Tang, L. H. Tan, X. Wang, N. S. R. Satyavolu, H. Xing, Z. Wang, J. Li, H. Liang, and Y. Lu. 2015a. DNA-encoded tuning of geometric and plasmonic properties of nanoparticles growing from gold nanorod seeds. Angew. Chem. Int. Ed. Engl. 54:8114-8118.

Song, X., S. Shukla, S. Oh, Y. Kim, and M. Kim. 2015b. Development of fluorescence-based liposome immunoassay for detection of Cronobacter muytjensii in pure culture. Curr. Microbiol. 70:246252

Storhoff, J. J., R. Elghanian, C. A. Mirkin, and R. L. Letsinger. 2002. Sequence-dependent stability of DNA-modified gold nanoparticles. Langmuir 18:6666-6670.

Tan, L., Z. Chen, C. Zhang, X. Wei, T. Lou, and Y. Zhao. 2017. Colorimetric detection of $\mathrm{Hg}^{2+}$ based on the growth of aptamercoated AuNPs: The effect of prolonging aptamer strands. Small $13: 1603370$.

Tan, L. H., H. Xing, and Y. Lu. 2014. DNA as a powerful tool for morphology control, spatial positioning, and dynamic assembly of nanoparticles. Acc. Chem. Res. 47:1881-1890.

Tang, Y., F. Feng, F. He, S. Wang, Y. Li, and D. Zhu. 2006. Direct visualization of enzymatic cleavage and oxidative damage by hydroxyl radicals of single-stranded DNA with a cationic polythiophene derivative. J. Am. Chem. Soc. 128:14972-14976.

Wang, Z., L. Tang, L. H. Tan, J. Li, and Y. Lu. 2012. Discovery of the DNA "genetic code" for abiological gold nanoparticle morphologies. Angew. Chem. Int. Ed. Engl. 51:9078-9082.

Wang, Z., J. Zhang, J. M. Ekman, P. J. Kenis, and Y. Lu. 2010. DNAmediated control of metal nanoparticle shape: One-pot synthesis and cellular uptake of highly stable and functional gold nanoflowers. Nano Lett. 10:1886-1891.

Wu, J., L. H. Tan, K. Hwang, H. Xing, P. Wu, W. Li, and Y. Lu. 2014. DNA sequence-dependent morphological evolution of silver nanoparticles and their optical and hybridization properties. J. Am. Chem. Soc. 136:15195-15202.

Wu, L., G. Li, X. Xu, L. Zhu, R. Huang, and X. Chen. 2019. Application of nano-ELISA in food analysis: recent advances and challenges. TrAC Trends in Analytical Chemistry 113:140-156.

Xiong, Y., B. Gao, K. Wu, Y. Wu, Y. Chai, X. Huang, and Y. Xiong. 2018a. Fluorescence immunoassay based on the enzyme cleaving ss-DNA to regulate the synthesis of histone-ds-poly (AT) templated copper nanoparticles. Nanoscale 10:19890-19897.

Xiong, Y., K. Pei, Y. Wu, H. Duan, W. Lai, and Y. Xiong. 2018b. Plasmonic ELISA based on enzyme-assisted etching of Au nanorods for the highly sensitive detection of aflatoxin $\mathrm{B}_{1}$ in corn samples. Sens. Actuators B Chem. 267:320-327.

Xiong, Y., K. Zhang, B. Gao, Y. Wu, X. Huang, W. Lai, Y. Xiong, and Y. Liu. 2019. Fluorescence immunoassay through histone-dspoly (AT)-templated copper nanoparticles as signal transductors for the sensitive detection of Salmonella choleraesuis in milk. J. Dairy Sci. 102:6047-6055.

Zhang, Z., H. Wang, Z. Chen, X. Wang, J. Choo, and L. Chen. 2018. Plasmonic colorimetric sensors based on etching and growth of noble metal nanoparticles: Strategies and applications. Biosens. Bioelectron. 114:52-65. 